\title{
Hubungan antara Pola Sidik Bibir dan Jenis Suku Melayu Riau
}

\author{
Dedi Afandi, ${ }^{1}$ Melissa Mandatasari ${ }^{2}$ \\ ${ }^{1}$ Kelompok Jabatan Fungsional Kedokteran Forensik dan Studi Medikolegal Fakultas Kedokteran Universitas Riau, \\ ${ }^{2}$ Fakultas Kedokteran Universitas Riau
}

\begin{abstract}
Abstrak
Sidik bibir telah lama digunakan sebagai salah satu metode identifikasi individu. Penelitian hubungan pola sidik bibir dengan jenis suku belum banyak diteliti, khususnya di Indonesia. Penelitian ini bertujuan mendapatkan hubungan pola sidik bibir antara galur murni suku Melayu Riau dan suku bukan Melayu Riau. Penelitian studi potong lintang dilakukan di Fakultas Kedokteran Universitas Riau antara bulan Juli sampai Agustus tahun 2015. Sebanyak 160 mahasiswa memenuhi kriteria sampel penelitian dengan metode pengambilan sampel secara acak sederhana. Kriteria eksklusi adalah mahasiswa Fakultas Kedokteran yang mengalami kelainan anatomi pada bibirnya (labiochisis/ labiopalatochisis), pascatrauma, dan alergi terhadap lipstik. Metode Vahanwal-NayakPagare digunakan untuk mencetak pola sidik bibir. Pola sidik bibir ditetapkan dengan menggunakan klasifikasi Suzuki dan Tsuchihashi pada kedelapan kuadran bibir. Jenis suku terbanyak adalah suku bukan Melayu Riau 111 $(69,4 \%)$ dibanding dengan galur murni suku Melayu Riau 49(30,6\%). Uji statistik menunjukkan hubungan yang signifikan hanya pada kuadran $3(\mathrm{p}=0,04)$. Dapat disimpulkan bahwa pola sidik bibir dapat digunakan untuk metode alternatif identifikasi personal, akan tetapi tidak dapat digunakan untuk membedakan galur murni suku Melayu Riau dengan bukan Melayu Riau pada populasi penelitian. [MKB. 2017;49(4):231-6]
\end{abstract}

Kata kunci: Klasifikasi Suzuki dan Tsuchihashi, sidik bibir, suku melayu Riau

\section{Association between Lip Print Pattern and Riau Malay Ethnics}

\begin{abstract}
Lip print have long been used as one of the personal identification methods. Studies on the lip print pattern associated with ethnicity has not been widely available, especially in Indonesia. This was a study aimed to identify association between lip printi patterns and pure strains of Riau Malay and non-Malay Riau. A crosssectional study was conducted at the Faculty of Medicine, University of Riau, between July to August 2015. A total of 160 students who met the criteria were selected through simple random sampling. Exclusion criteria were lip anatomic abnormalities (labiochisis/labiopalatochisis), post trauma experience, and allergic to lipstick. The Vahanwal-Nayak-Pagare method was used for printing the lip pattern. Lip print pattern was established using Suzuki and Tsuchihashi classification on eight lip quadrants. Most subjects were non-Malay Riau 111 (69.4\%) with the remainings were identified as $(n=49,30.6 \%)$. The statistical test showed a significant relation only in Quadrant $3(\mathrm{p}=0,04)$. It is concluded that lip print pattern can be used as an alternative method in personal identification; however, it cannot be used to distinguish the pure strains of the Riau Malay ethnics from the nonRiau Malay ethnics in the study population. [MKB. 2017;49(4):231-6]
\end{abstract}

Key words: Lip print, Riau Malay ethnic, Suzuki and Tsuchihashi classification

Korespondensi: Dr. Dedi Afandi, D.F.M., Sp.F, Kelompok Jabatan Fungsional (KJF) Kedokteran Forensik dan Studi Medikolegal, Fakultas Kedokteran Universitas Riau, Jalan Diponegoro No. 1 Pekanbaru, Riau E-mail: dediafandi4n6@gmail.com 


\section{Pendahuluan}

Sidik bibir telah lama digunakan sebagai salah satu metode identifikasi individu. Sidik bibir bersifat personal, unik, dan khas pada seseorang sehingga dapat digunakan untuk identifikasi individu. Penelitian yang dilakukan oleh Tsuchihashi ${ }^{1}$ pada tahun 1974 melaporkan bahwa tidak ditemukan pola sidik bibir yang sama dari 1364 subyek penelitian. ${ }^{2}$ Penentuan identitas personal dapat dilakukan dengan menggunakan dua metode identifikasi, yaitu identifikasi primer seperti pemeriksaan sidik jari, DNA, gigi, dan metode identifikasi sekunder seperti, pemeriksaan visual, fotografi, properti, medis, termasuk pemeriksaan sidik bibir. ${ }^{3}$

Sidik bibik memiliki beberapa keunggulan, yaitu relatif mudah dan murah untuk digunakan, tidak berubah mulai manusia berusia 6 minggu pada masa kehamilan sampai dengan meninggal sehingga bersifat permanen, serta dapat digunakan sebagai petunjuk untuk membedakan jenis kelamin..$^{2-7}$ Sidik bibir bersifat genetik dan individual. Anak-anak memiliki pola sidik bibir yang sama dengan orangtua mereka walaupun lokasinya berbeda (berada pada kuadran bibir yang berbeda) sehingga sidik bibir dari setiap orang bersifat unik, dan berbeda antara satu orang dengan orang lainnya. ${ }^{8}$ Sidik bibir terbentuk pada saat permukaan bibir bersentuhan dengan permukaan lain, misalnya permukaan gelas. Dalam suatu kasus kriminal, sidik bibir sering ditemukan pada gelas kaca, surat cinta, dan beberapa objek lain pada tempat kejadian perkara. Sidik bibir yang terdapat pada permukaan objek tersebut dapat dibandingkan dengan sidik bibir dari tersangka ataupun korban, sehingga hasil pemeriksaan sidik bibir tersebut dapat dijadikan sebagai salah satu alat bukti untuk kepentingan identifikasi forensik. Berdasarkan hal yang telah diuraikan maka sidik bibir dapat digunakan sebagai metode identifkasi individu serta dapat dijadikan bukti baik untuk kepentingan medikolegal maupun nonmedikolegal. ${ }^{3,5,9}$

Penelitian pola sidik bibir pada suku tertentu belum banyak diteliti, khususnya di Indonesia. Penelitian pola sidik bibir pada galur murni suku Melayu Riau belum pernah dilakukan. Suku melayu Riau dipilih karena merupakan salah satu suku yang dominan dan kota Pekanbaru, Riau. Suku Melayu Riau tersebar dan mendiami sebagian besar daerah di Provinsi Riau sehingga untuk mendapatkan galur murni suku Melayu Riau relatif lebih mudah didapatkan. Tujuan penelitian ini adalah mendapatkan hubungan pola sidik bibir antara galur murni suku Melayu Riau dan suku bukan Melayu Riau.

\section{Metode}

Jenis penelitian ini adalah penelitian analitik dengan pendekatan potong lintang. Penelitian ini dilakukan di Fakultas Kedokteran Universitas Riau dari bulan Juli hingga Agustus 2015. Sebanyak 160 mahasiswa Fakultas Kedokteran memenuhi kriteria sampel penelitian dengan metode pengambilan sampel secara acak sederhana. Kriteria eksklusi adalah mahasiswa Fakultas Kedokteran yang mengalami kelainan anatomi pada bibirnya (labiochisis/ labiopalatochisis), pascatrauma, dan alergi terhadap lipstik. Variabel dalam penelitian ini adalah jenis suku, kuadran, dan tipe pola sidik bibir. Jenis suku terbagi dua, yaitu suku melayu Riau dan non melayu Riau. Suku melayu Riau adalah galur murni Melayu Riau, sampai 2 generasi ke atas merupakan suku melayu Riau. Setiap subjek penelitian menandatangani formulir persetujuan penelitian setelah mendapatkan penjelasan dari peneliti.

Alat dan bahan yang digunakan pada penelitian ini adalah lipstik berwarna agak gelap, cermin, cottonbud, kertas A4 70 gsm, pena/pensil untuk melabel kertas, kaca pembesar (lup) $\varnothing$ $75 \mathrm{~mm}$ dan penggaris. Metode yang digunakan dalam penelitian ini menggunakan metode yang dilakukan oleh Vahanwal dkk. ${ }^{10}$

Seluruh subjekmengisi data diri dan jenis suku pada kertas A4 70 gsm yang telah disediakan, kemudian subjek diminta untuk mengoleskan lipstik dengan menggunakan cottonbud dan meratakannya. Subjek diminta untuk menggosok kedua bibir untuk menyebarkan lipstik pada bagian atas dan bawah, sehingga lipstik merata menutupi seluruh permukaan. Diperiksa oleh peneliti apakah lipstik sudah terdapat pada semua kuadran bibir. Pencetakan dilakukan dengan cara menempelkan bibir ke kertas yang ditempelkan ke dinding dengan posisi bibir terkatup dan setengah mencucu sehingga seluruh permukaan bibir tercetak dan dapat menunjukkan fissures serta grooves dengan baik dan benar. Sidik bibir yang tercetak kemudian ditentukan tipe-tipenya di 8 kuadran.

Kuadran merupakan pembagian bibir dengan membagi bibir atas dan bawah masing-masing menjadi 4 bagian dengan menarik garis median yang tepat melewati cupid's bow dan garis paramedian sehingga akan dapat ditentukan menjadi 8 kuadran. Tipe pola sidik bibir 
merupakan tipe pola sidik bibir yang berdasar atas klasifikasi Suzuki dan Tsuchihashi ${ }^{1}$ (Tabel 1).

Penentuan tipe pada tiap kuadran berdasar atas tipe yang paling dominan pada tiap-tiap kuadran yang dilakukan oleh 2 orang yang telah dilatih dengan nilai Kappa 0,82.

Data hasil penelitian yang telah dikumpulkan ditabulasi kemudian disajikan dalam bentuk tabel distribusi frekuensi dan persentase. Dilakukan uji Kai-Kuadrat atau uji alternatif untuk menentukan hubungan antara jenis suku dan tipe pola sidik bibir dengan siginifikansi $\mathrm{p}<0,05$.

\section{Hasil}

Berdasar atas data yang telah dikumpulkan, dari 160 sampel didapatkan 49 orang $(30,6 \%)$ adalah suku Melayu Riau dan 111 orang $(69,4 \%)$ bukan suku Melayu Riau.

Dari data tipe pola sidik bibir berdasar atas kuadran (Tabel 2), dapat diketahui bahwa pola sidik bibir Tipe IV tidak ditemukan pada kuadran I dari semua subjek penelitian, namun Tipe I dominan ditemukan pada kuadran 7 $(63,8 \%)$. Pada kuadran 2, dominan ditemukan tipe II (40\%) dan tipe I $(34,4 \%)$. Pola sidik bibir Tipe I' ditemukan kurang dari 10\% pada

Tabel 1 Klasifikasi Suzuki dan Tsuchihashi

\begin{tabular}{|c|c|c|}
\hline Tipe & Gambar & Deskripsi \\
\hline I - Full Vertical Grooves & & $\begin{array}{l}\text { Terlihat pola alur vertikal pada } \\
\text { seluruh bagian bibir }\end{array}$ \\
\hline I' - Short Vertical Grooves & & $\begin{array}{l}\text { Terlihat mirip seperti tipe I namun } \\
\text { pola alur tidak pada seluruh bagian } \\
\text { bibir }\end{array}$ \\
\hline II- Branched Grooves & & Terlihat pola alur yang bercabang \\
\hline III - Diamond Grooves & & $\begin{array}{l}\text { Terlihat pola alur yang saling } \\
\text { menyilang }\end{array}$ \\
\hline IV - Rectangular Grooves & & $\begin{array}{l}\text { Terlihat pola alur yang membentuk } \\
\text { kotak- kotak }\end{array}$ \\
\hline V - Irregular & & $\begin{array}{l}\text { Pola alur yang bukan salah satu } \\
\text { dari tipe-tipe di atas atau pola alur } \\
\text { bentuk lainnya }\end{array}$ \\
\hline
\end{tabular}


Tabel 2 Distribusi Frekuensi Tipe Pola Sidik Bibir berdasar atas Kuadran

\begin{tabular}{|c|c|c|c|c|c|c|}
\hline \multirow{2}{*}{ Kuadran } & \multicolumn{6}{|c|}{ Tipe Pola Sidik Bibir } \\
\hline & $\begin{array}{c}\text { I } \\
\text { n (\%) }\end{array}$ & $\begin{array}{c}\text { I' } \\
\text { n (\%) }\end{array}$ & n (I $)$ & $\begin{array}{c}\text { III } \\
\text { n (\%) }\end{array}$ & $\begin{array}{c}\text { IV } \\
\text { n (\%) }\end{array}$ & $\begin{array}{c}\text { V } \\
\text { n (\%) }\end{array}$ \\
\hline 1 & $29(18,1)$ & $7(4,4)$ & $96(60,0)$ & $17(10,6)$ & $0(0,0)$ & $11(6,9)$ \\
\hline 2 & $55(34,4)$ & $5(3,1)$ & $64(40,0)$ & $9(5,6)$ & 18 (11.3) & $9(5,6)$ \\
\hline 3 & $55(34,4)$ & $9(5,6)$ & $59(36,9)$ & $7(4,4)$ & $19(11,9)$ & $11(6,9)$ \\
\hline 4 & $24(15,0)$ & $5(3,1)$ & $92(57,5)$ & $18(11,3)$ & $3(1,9)$ & $18(11,3)$ \\
\hline 5 & $10(6,3)$ & $8(5,0)$ & $107(66,9)$ & $15(9,4)$ & $3(1,9)$ & $17(10,6)$ \\
\hline 6 & $82(51,3)$ & $4(2,5)$ & $60(37,5)$ & $4(2,5)$ & $8(5,0)$ & $2(1,3)$ \\
\hline 7 & $102(63,8)$ & $1(0,6)$ & $38(23,8)$ & $5(3,1)$ & $5(3,1)$ & $9(5,6)$ \\
\hline 8 & $13(8,1)$ & $4(2,5)$ & $114(71,3)$ & $18(11,3)$ & $4(2,5)$ & $7(4,4)$ \\
\hline
\end{tabular}

Tabel 3 Perbandingan Proporsi Pola Sidik Bibir berdasar atas Kuadran dan Jenis Suku

\begin{tabular}{|c|c|c|c|c|c|c|c|c|}
\hline \multirow[b]{2}{*}{ Kuadran } & \multirow[b]{2}{*}{ Jenis Suku } & \multicolumn{6}{|c|}{ Tipe Pola Sidik Bibir } & \multirow[b]{2}{*}{ p } \\
\hline & & $\begin{array}{c}\text { I } \\
\text { n (\%) }\end{array}$ & $\begin{array}{c}I^{\prime} \\
\text { n (\%) }\end{array}$ & $\begin{array}{c}\text { II } \\
\text { n (\%) }\end{array}$ & $\begin{array}{c}\text { III } \\
\text { n (\%) }\end{array}$ & $\begin{array}{c}\text { IV } \\
\text { n (\%) }\end{array}$ & $\begin{array}{c}\text { V } \\
\text { n (\%) }\end{array}$ & \\
\hline \multirow[t]{3}{*}{1} & Melayu Riau & $10(34,5)$ & $0(0,0)$ & $28(29,2)$ & $8(47,1)$ & $0(0,0)$ & $3(27,3)$ & 0,490 \\
\hline & Bukan Melayu Riau & $19(65,5)$ & $7(100)$ & $68(70,8)$ & $9(52,9)$ & $0(0,0)$ & $8(72,7)$ & \\
\hline & Total & $29(100)$ & $7(100)$ & $96(100)$ & $17(100)$ & $0(0,0)$ & $11(100)$ & \\
\hline \multirow[t]{3}{*}{2} & Melayu Riau & $18(32,7)$ & $2(40)$ & $19(29,7)$ & $2(22,2)$ & $6(33,3)$ & $2(22,2)$ & 0,578 \\
\hline & Bukan Melayu Riau & $37(67,3)$ & $3(60)$ & $45(70,3)$ & $7(77,8)$ & $12(66,7)$ & $7(77,8)$ & \\
\hline & Total & $55(100)$ & $5(100)$ & $64(100)$ & $9(100)$ & $18(100)$ & $9(100)$ & \\
\hline \multirow[t]{3}{*}{3} & Melayu Riau & $22(40)$ & $3(33,3)$ & $16(26,1)$ & $0(0,0)$ & $8(42,1)$ & $0(0,0)$ & $0,041^{*}$ \\
\hline & Bukan Melayu Riau & $33(60)$ & $6(66,7)$ & $4372,9)$ & $7(100)$ & $11(57,9)$ & $11(100)$ & \\
\hline & Total & $55(100)$ & $9(100)$ & $59(100)$ & $7(100)$ & $19(100)$ & $11(100)$ & \\
\hline \multirow[t]{3}{*}{4} & Melayu Riau & $6(25)$ & $1(25)$ & $29(31,5)$ & $6(33,3)$ & $2(67,7)$ & $5(27,8)$ & 0,484 \\
\hline & Bukan Melayu Riau & $18(75)$ & $4(75)$ & $63(68,5)$ & $12(66,7)$ & $1(33,3)$ & $13(72,2)$ & \\
\hline & Total & $24(100)$ & $5(100)$ & $92(100)$ & $18(100)$ & $3(100)$ & $18(100)$ & \\
\hline \multirow[t]{3}{*}{5} & Melayu Riau & $4(40)$ & $3(37,5)$ & $32(29,9)$ & $6(30)$ & $0(0,0)$ & $4(23,5)$ & 0,454 \\
\hline & Bukan Melayu Riau & $6(60)$ & $5(62,5)$ & $7570,1)$ & $9(60)$ & $3(100)$ & 13 & \\
\hline & Total & $10(100)$ & $8(100)$ & $107(100)$ & $15(100)$ & $3(100)$ & $\begin{array}{c}(76,5) \\
17(100)\end{array}$ & \\
\hline \multirow[t]{4}{*}{6} & Melayu Riau & $28(34,1)$ & $0(0,0)$ & $15(25)$ & $1(25)$ & $4(50)$ & & 0,654 \\
\hline & Bukan Melayu Riau & $54(65,9)$ & $4(100)$ & $45(75)$ & $3(75)$ & $4(50)$ & $1(50)$ & \\
\hline & Total & $82(100)$ & $4(100)$ & $60(100)$ & $4(100)$ & $8(100)$ & $1(50)$ & \\
\hline & & & & & & & $2(100)$ & \\
\hline \multirow[t]{4}{*}{7} & Melayu Riau & $36(35,3)$ & $0(0,0)$ & $6(15,8)$ & $1(20)$ & $3(60)$ & & 0,198 \\
\hline & Bukan Melayu Riau & $66(64,7)$ & $1(100)$ & $32(84,2)$ & $4(80)$ & $2(40)$ & $3(33,3)$ & \\
\hline & Total & $102(100)$ & $1(100)$ & $38(100)$ & $5(100)$ & $5(100)$ & $6(66,7)$ & \\
\hline & & & & & & & $9(100)$ & \\
\hline \multirow[t]{4}{*}{8} & Melayu Riau & $4(30,8)$ & $1(25)$ & $36(31,6)$ & $7(38,9)$ & $0(0,0)$ & & 0,716 \\
\hline & Bukan Melayu Riau & $9(69,2)$ & $3(75)$ & $78(68,4)$ & $11(61,1)$ & $4(100)$ & $1(14,3)$ & \\
\hline & Total & $13(100)$ & $4(100)$ & $114(100)$ & $18(100)$ & $4(100)$ & $6(85,7)$ & \\
\hline & & & & & & & 7 (100) & \\
\hline
\end{tabular}


semua kuadran. Pola sidik bibir tipe II dominan ditemukan pada kuadran 8 (71,3\%) dan kuadran $5(66,9 \%)$.

Perbandingan tipe pola sidik bibir antara galur murni suku Melayu Riau dan bukan suku Melayu Riau pada delapan kuadran dapat dilihat pada Tabel 3. Dari data hasil penelitian dapat dilihat bahwa pola sidik bibir tipe I, I', II, dan III lebih dominan pada suku bukan Melayu Riau pada semua kuadran dengan angka proporsi berkisar antara 52,9-100 \%. Pada galur murni suku melayu Riau, pola sidik bibir tipe I' tidak ditemukan pada 3 kuadran, tipe IV pada 2 kuadran dan tipe II serta tipe $\mathrm{V}$ masing-masing pada satu kuadran. Tipe IV tidak ditemukan pada kuadran 1 untuk semua jenis suku yang dibandingkan. Hasil uji satistik menunjukkan perbedaan yang signifikan pola bibir tipe $\mathrm{V}$ antara galur murni suku Melayu Riau dan bukan suku Melayu Riau ( $p=0,041)$.

\section{Pembahasan}

Dari penelitian yang telah dilakukan, tidak ditemukan pola sidik bibir yang identik di antara populasi yang diteliti. Hasil ini sejalan dengan penelitian yang telah dilakukan dari tahun 1974 sampai dengan saat ini. ${ }^{2-5,8,11-15}$ Temuan ini semakin memperkuat teori dan hasil penelitian sebelumnya bahwa pola sidik bibir dapat digunakan sebagai identifikasi personal. Penelitian dengan menggunakan berbagai metode dan klasifikasi juga menunjukkan bahwa pola sidik bibir bersifat unik dan personal. ${ }^{12,13,15,16}$ Penggunaan pola sidik bibir pada bidang kedokteran forensik adalah dengan membandingkan data pola sidik bibir pada individu dengan pola sidir bibir yang ditemukan pada objek atau benda di sekitar tempat kejadian perkara. Semakin banyak metode identifikasi yang digunakan maka hasilnya akan semakin dapat dipercaya. ${ }^{2-5,7,9,11}$ Suzuki dan Tsuchihashi pernah membuat publikasi 2 laporan kasus yang berhubungan dengan pemanfaatan pola sidik bibir untuk kepentingan hukum dan peradilan dengan cara membantu penyidik mengidentifikasi korban berdasarkan pola sidik bibir. $^{5}$

Dari hasil penelitian menunjukkan galur murni suku melayu Riau cenderung jarang memiliki pola sidik bibir tipe I', tipe IV, tipe II, dan tipe V. Pola sidik bibir tipe II merupakan pola sidik bibir yang tidak cukup adequat untuk dapat membedakan galur murni suku Melayu Riau dengan suku bukan Melayu Riau karena sama-sama dominan pada kedua kelompok suku yang diteliti.

Penelitian lain yang menghubungkan antara pola sidik bibir dan jenis suku atau populasi tertentu adalah penelitian yang dilakukan oleh Nagpal dkk. ${ }^{13}$ serta Parmar dan Rathod ${ }^{16}$ di Malaysia serta Azis dkk. ${ }^{17}$ yang membandingkan antara populasi Mesir dan Malaysia, ketiga penelitian ini menggunakan metode klasifikasi Suzuki dan Tsuchihashi. Klasifikasi Suzuki dan Tsuchihashi lebih banyak digunakan dan lebih popular dibanding dengan metode klasifikasi lain karena metode ini relatif lebih mudah digunakan. Klasifikasi lain yang dapat digunakan adalah kalsifikasi Santos, Renaud, Afchar-Bayat, dan Kasprzak. ${ }^{11}$

Penelitian pola sidik bibir yang pernah dilakukan di Indonesia dengan menggunakan klasifikasi Suzuki dan Tsuchihashi adalah penelitian yang dilakukan oleh Qomariah dkk. ${ }^{18}$ di Jember dan Toppo dkk. ${ }^{19}$ di Makassar. Meskipun menggunakan metode klasifikasi yang sama dengan penelitian ini, penelitian di Jember bertujuan membuktikan adanya hubungan antara pola sidik bibir dengan jenis kelamin. ${ }^{18}$ Sementara itu, penelitian di Makassar membuktikan bahwa tidak terdapat perbedaan pola sidik bibir individu pada posisi normal, terbuka, tersenyum, dan mengecup. ${ }^{19} \mathrm{Hal}$ ini menunjukkan bahwa metode pengambilan sidik bibir yang dilakukan pada penelitian ini dengan posisi bibir terkatup dan setengah mencucu (mengecup) dapat dipercaya sebagai cetakan pola sidik bibir yang sebenarnya.

Dari penelitian ini didapatkan tidak ada hubungan yang signifikan antara pola sidik bibir pada galur murni suku Melayu Riau dengan suku bukan Melayu Riau, kecuali pada kuadran $3(p=0,04)$. Hasil yang sama juga didapatkan pada penelitian Nagpal dkk. ${ }^{13}$ dan Parmar dan Rathod ${ }^{16}$ bahwa tidak hubungan yang signifikan pola sidik bibir antara suku yang dibandingkan. Sementara itu, penelitian di Mesir mendapatkan hasil yang signifikan pada kuadran 2 populasi yang diteliti. ${ }^{17}$

Penelitian di Nigeria ${ }^{20}$ yang melakukan studi perbandingan pola sidik bibir pada 3 suku (Hausa, Yoruba dan Igbo), dan penelitian yang dilakukan oleh Devi dkk. ${ }^{9}$ juga memperlihatkan hasil yang kurang lebih sama bahwa tipe pola sidik bibir tertentu hanya bersifat predominan pada satu suku dibandingkan suku lain dan tidak ditemukan hubungan yang signifikan antara tipe pola sidik bibir dan jenis suku. Namun, hasil penelitian-penelitian yang telah dilakukan dengan menggunakan tipe pola sidik bibir perlu 
terus dilakukan, setidaknya tipe pola sidik bibir memiliki potensi yang cukup menjanjikan untuk digunakan sebagai metode pelengkap dalam proses identifikasi suku dan personal. Selain itu pada penelitian Saudi Arabia ${ }^{6}$ dilaporkan bahwa pola sidik bibir bersifat stabil dan tidak berubah setelah 3 tahun pada populasi yang diteliti.

Penelitian ini memiliki keterbatasan, yaitu suku bukan Melayu Riau dapat berasal atau campuran dari suku Melayu Riau itu sendiri. Untuk itu disarankan melakukan penelitian perbandingan pada dua atau lebih suku dengan galur murni.

Simpulan, pola sidik bibir dapat digunakan untuk metode alternatif identifikasi personal, akan tetapi tidak dapat dipergunakan untuk membedakan galur murni suku Melayu Riau dan bukan Melayu Riau pada populasi penelitian. Disarankan untuk dilakukan penelitian lanjutan dengan jumlah sampel yang lebih besar dan mempergunakan metode klasifikasi lain untuk menentukan pola sidik bibir.

\section{Daftar Pustaka}

1. Tsuchihashi Y. Studies on personal identification by means of lip prints. J Forensic Sci. 1974;3:233_48.

2. Caldas IM, Magalhães T, Afonso A. Establishing identity using cheiloscopy and palatoscopy. Forensic Sci Int. 2007;165(1):1-9.

3. Remya S, Priyadarshini T, Umadethan B, Gopalan M, Jeyaseelan N. Cheiloscopy - A study of lip prints for personal identification. IOSR J Dent Med Sci. 2016;15(2):2279-81.

4. Mishra G, Ranganathan K, Saraswathi T, Mishra G, Ranganathan K, Saraswathi T. Study of lip prints. J Forensic Dent Sci. 2009;1(1):28-31.

5. Ramalingam K, Rehman F, Sethuraman S, Kinra M, Lalawat G, Pandey A. Cheiloscopy for sex determination: a study. Univers Res J Dent. 2014;4(1):48-51.

6. Eldomiaty MA, Anwar RI, Algaidi SA. Stability of lip-print patterns: a longitudinal study of Saudi females. J Forensic Leg Med. 2014;22:154-8.

7. George R, Afandi NSBN, Abidin SNHBZ, Ishak NI, Soe HHK, Ismail ARH. Inheritance pattern of lip prints among Malay population: A pilot study. J Forensic Leg Med. 2016;39:156-60.

8. Kannan S, Muthu K, Muthusamy S, Sidhu
P. Cheiloscopy-A vital tool in crime investigation. Int $\mathrm{J}$ Forensic Sci Pathol. 2015;3(3):89-93.

9. Devi A, Astekar M, Kumar V, Kaur P, Singh N, Sidhu GK. The study of inheritance analysis and evaluation of lip prints in individuals. J Forensic Dent Sci. 2015;7(1):49-53.

10. Vahanwala S, Nayak CD, Pagare SS. Study of lip-prints as aid for sex Determination. Medico-Legal Update. 2005; 5: 7-9.

11. Ranjan V, Sunil M, Kumar R. Study of lip prints: a forensic study. J Indian Acad Oral Med Radiol. 2014;26(1):50-4.

12. Moshfeghi M, Beglou A, Mortazavi H, Bahrololumi N. Morphological patterns of lip prints in an Iranian population. J Clin Exp Dent. 2016;(5):e550-5.

13. Nagpal B, Hegde U, Sreeshyla HS, Arun M. Comparative evaluation of lip prints among Indian and Malaysian students. J Indian Acad Forensic Med. 2015;37(2):131-4.

14. Augustine J, Barpande SR, Tupkari JV. Cheiloscopy as an adjunct to forensic indentication: A study of 600 individuals. J Forensic Odontostomatol. 2008;26(2):4452.

15. Prabhu RV, Dinkar A, Prabhu V. A study of lip print pattern in Goan dental studentsa digital approach. J Forensic Leg Med. 2012;19(7):390-5.

16. Parmar P, Rathod G. Pattern of lip print among undergraduate students: a forensic anthropologic study. International Archives of Integrated Medicine. 2017;4(5):52-5.

17. Aziz MHA, Badr FMM, Saeed NMM. Regression equations for sex and population detection using the lip print pattern among Egyptian and Malaysian adult. J Forensic Leg Med. 2016;44:103-10.

18. Qomariah SN, Novita M, Wulandari E. Hubungan antara pola sidik bibir dengan jenis kelamin pada mahasiswa Fakultas Kedokteran Gigi Universitas Jember. eJurnal Pustaka Kesehat. 2015;2(2):231-6.

19. Toppo S, Rieuwpassa IE, Lisal JI, Sari US. Gambaran sidik bibir mahasiswa pada Fakultas Kedokteran Gigi Universitas Hasanuddin. Dentofasial. 2014;13(1):13-6.

20. Adamu LH, Taura MG, Hamman WO, Ojo SA, Dahiru AU, Sadeeq AA, dkk. Study of lip print types among Nigerians. HOMO-Journal Comp Hum Biol. 2015;66(6):561-9. 